\title{
Serological Follow-up of Trypanosoma cruzi Infection from 1987 to 1994 in 32 Counties of the State of Jalisco, Mexico (Preliminary Report)
}

Seguimento Sorológico de Infecção por Trypanosoma cruzi entre 1987 e
1994 em 32 Municípios do Estado de Jalisco, México (Relatório Preliminar)

\author{
Francisco Trujillo-Contreras ${ }^{1}$ \\ Maria Angeles V. Yerenas ${ }^{1}$
}

TRUJILLO-CONTRERAS, F. \& YERENAS, M. A. V. Serological Follow-up of T. cruzi Infection from 1987 to 1994 in 32 Counties of the State of Jalisco, Mexico (Preliminary Report). Cad. Saúde Públ., Rio de Janeiro, 11 (3): 501-505, Jul/Sep, 1995.

In 1987 the University of Guadalajara performed a seroepidemiological survey on the prevalence of Chagas' disease in the 124 counties of the State of Jalisco, Mexico, arriving at a rate of 21.6 per 100 inhabitants. From December 1993 to June 1994, we studied 2238 individuals from 32 rural counties in this State. Of these, we found 276 positives $(12.33 \%)$ and 1962 negatives (87.66\%). Nevertheless, the series of serological differences found are very striking, since out of the 655 individuals that were seropositive in 1987, we noted that 276 individuals remained positive, while 50 individuals (7.63\%) became negative. There were no flaws in the laboratory techniques. We believe that either the immune response of Mexicans is different or that the virulence of the Mexican strains of Trypanosoma cruzi may be not as great as that in the South America countries.

Key words: Chagas' Disease; Serology; Trypanosoma cruzi Infection

\section{INTRODUCTION}

Chagas disease is caused by a hemoflagellate protozoan producing varied clinical manifestations in humans. Many patients have an indeterminate, asymtomatic form of the disease. Some of these patients can develop lesions 10 or 20 years after the infection, $20 \%$ to $30 \%$ develop the cardiac form of the disease (Prata, 1985), and around $7 \%$ have megaesophagus (Castro et al., 1984). The prevalence of patients with megacolon is still unclear.

Mazzoti (1940), while attempting to diagnose malaria, made the discovery of the

\footnotetext{
${ }^{1}$ Centro de Investigación de Enfermedades Tropicales, Centro Universitario de Ciencias de la Salud, Universidad de Guadalajara. Carlos Merida, No. 348, Colinas de la Normal, CP. 44270, Guadalajara, Jalisco, Mexico.
}

first two human cases of Chagas' disease in Mexico in 1940. In the State of Jalisco, Cuartero et al. (1967) reported the first two cases of this disease in the county of Santa Maria de los Angeles. Later, in 1986, the most important outbreak of acute Chagas' disease of those reported thus far was detected in the county of Tuxcueca, Jalisco. Eleven individuals out of a familiy of 14 began to display the characteristic symptomatology (Hernandez et al., 1987).

In response to these events, the University of Guadalajara decided in 1987 to perform a seroepidemiological survey to measure the prevalence of Chagas' disease in the 124 counties of the State of Jalisco, arriving at a rate of 21.6 per 100 inhabitants (TrujilloContreras et al., 1987).

However, despite this very high rate of infection, from 1940 to 1994 only approximately 300 acute cases and 300 
chronic cases have been reported in Mexico (Instituto Nacional de Diagnostico y

Referencia, 1991). This is extremely interesting, since Mexico has the same environmental conditions (ecosystems), reservoirs, and parasites as those found in South America (Instituto Nacional de Diagnostico y

Referencia, 1991), but we do not have the same high numbers of diseased persons as South American countries.

For this reason, the decision was made to perform a serological follow-up of $T$. cruzi infection in the same individuals studied in 1987 to see what changes, had ocurred over a seven-year period, formulating a negative hypothesis where we did not expect to find changes in the individuals with positive and negative serology.

The purpose of this follow-up study was to perform the Indirect Hemagglutination test on all the individuals, that were involved in the research in 1987 in the 124 municipalities of the State of Jalisco.

\section{MATERIAL AND METHODS}

From December 1993 to June 1994, peripheral blood samples were taken from the inhabitants of various municipalities in the rural areas of the State of Jalisco, including those mentioned in Table 1 of this preliminary report. Individuals born from 1987 on were excluded from the study, as were those who lived at the same address but were not previously included in the study. The characteristics of the dwelling were inspected to compare whether or not there had been any improvement in housing conditions. A search was made inside and outside the house for triatomids, and there was an attempt to identify signs and symptoms suggesting acute or chronic disease.

Samples were extracted by venipuncture and centrifuged at $2500 \mathrm{rpm}$ for 15 minutes. The serum was transported under refrigeration to the Center for Research on Tropical Diseases at the University of Guadalajara. A sample was also taken on Wattman paper number 1.

For processing the samples, the Indirect Hemagglutination technique was used with a procedure similar to that used by the Mario Fatala Chaben Institute in Argentina (Ministerio de Salud y Accion Social, 1985), but following the technique defined by the commercial antigen, Diagno Chagas, of Wiener Laboratories (Wiener Laboratorios). The Tulawen strain was used again so there would be no antigen variation in the test.

TABLE 1. Serological Diferences Found among the Studies of 1987 and 1993. Guadalajara, Jalisco, Mexico

\begin{tabular}{cccc}
\hline \hline Year & Individuals Studied & Positive & Negative \\
\hline 1987 & 2956 & $655(22.15 \%)$ & $2301(77.85 \%)$ \\
1994 & 2238 & $276(12,33 \%)$ & $1962(87.67 \%)$ \\
\hline \hline
\end{tabular}

\section{RESULTS}

A total of 2238 individuals were studied (75.71\% as compared to the 2956 tested in the 1987 study). Reasons for non-inclusion in the study were the following: migration -362 (16.17\%); refusal - 183 (8.17\%); death - 91 (4.06\%); and other causes -80 (3.57\%). Of the individuals studied, we found 276 positives
$(12.33 \%)$ and 1962 negatives (87.66\%), differing from the seropositivity rate of the 1987 study, which was $22.15 \%$ for these 32 municipalities (Table 2). Nevertheless, the series of serological differences we found were very striking, since out of the 655 individuals that ware seropositive in 1987, we noted that $50(7.63 \%)$ remained positive, while $20(7.24 \%)$ were discovered as new cases (Table 1). 
TABLE 2. Municipalities Studied in Serological Follow-Up of T. cruzi Infection with Percentual Distribution From 1987 to 1994. Guadalajara, Jalisco, Mexico

\begin{tabular}{|c|c|c|c|c|c|c|c|c|c|c|}
\hline \multirow{3}{*}{ Municipalities } & \multicolumn{5}{|c|}{ Year 1987} & \multicolumn{5}{|c|}{ Year 1994} \\
\hline & \multirow{2}{*}{$\begin{array}{c}\text { Individuals } \\
\text { Studied }\end{array}$} & \multicolumn{2}{|c|}{ Positives } & \multicolumn{2}{|c|}{ Negatives } & \multirow{2}{*}{$\begin{array}{c}\text { Individuals } \\
\text { Studied }\end{array}$} & \multicolumn{2}{|c|}{ Positives } & \multicolumn{2}{|c|}{ Negatives } \\
\hline & & № & $\%$ & № & $\%$ & & № & $\%$ & № & $\%$ \\
\hline Chapala & 72 & 0 & 0 & 72 & 100.0 & 48 & 1 & 2.0 & 47 & 98.0 \\
\hline Zapotiltic & 31 & 20 & 65.5 & 11 & 35.5 & 13 & 0 & 0 & 13 & 100.0 \\
\hline Guadalajara & 51 & 1 & 1.9 & 50 & 98.1 & 24 & 0 & 0 & 24 & 100.0 \\
\hline Santa Maria de los Angeles & 42 & 1 & 2.3 & 41 & 97.7 & 30 & 1 & 3.3 & 29 & 96.7 \\
\hline Tlajomulco de Zuñiga & 172 & 11 & 6.3 & 161 & 93.7 & 129 & 7 & 5.4 & 122 & 94.6 \\
\hline Tequila & 74 & 17 & 22.9 & 57 & 77.1 & 12 & 5 & 11.9 & 37 & 78.1 \\
\hline Techaluta & 91 & 12 & 13.1 & 79 & 86.9 & 61 & 8 & 13.1 & 53 & 86.9 \\
\hline Jarnay & 42 & 23 & 54.7 & 19 & 45.3 & 30 & 0 & 0 & 30 & 100.0 \\
\hline San Juan de los Lagos & 72 & 11 & 15.2 & 61 & 84.8 & 72 & 3 & 4.1 & 69 & 95.9 \\
\hline Zapopan & 140 & 53 & 37.8 & 87 & 62.2 & 75 & 14 & 18.6 & 61 & 81.4 \\
\hline Atenguillo & 67 & 23 & 34.3 & 44 & 65.7 & 54 & 17 & 11.4 & 37 & 68.6 \\
\hline Zapotiltic & 50 & 18 & 36.0 & 32 & 64.0 & 22 & 0 & 0 & 22 & 100.0 \\
\hline Tuxcueca & 196 & 18 & 24.4 & 148 & 75.6 & 103 & 19 & 18.4 & 84 & 81.6 \\
\hline San Martin Hidalgo & 50 & 23 & 46.0 & 27 & 54.0 & 28 & 10 & 15.7 & 18 & 64.3 \\
\hline Valle de Juarez & 92 & 11 & 11.9 & 81 & 88.1 & 58 & 11 & 18.9 & 47 & 81.1 \\
\hline Tonala & 108 & 47 & 43.5 & 61 & 56.5 & 40 & 2 & 5.0 & 38 & 95.0 \\
\hline Villa Purificación & 103 & 15 & 14.5 & 88 & 85.5 & 43 & 2 & 4.6 & 41 & 96.4 \\
\hline Extlahuacan de los Membrillos & 73 & 1 & 1.3 & 72 & 98.7 & 54 & 3 & 5.5 & 51 & 94.5 \\
\hline Degollado & 119 & 6 & 5.0 & 113 & 95.0 & 74 & 10 & 13.5 & 64 & 86.5 \\
\hline Arenal & 103 & 20 & 19.4 & 83 & 80.6 & 58 & 5 & 8.6 & 53 & 91.4 \\
\hline Tapalba & 27 & 13 & 48.1 & 14 & 51.9 & 22 & 0 & 0 & 22 & 100.0 \\
\hline Tototlan & 197 & 9 & 4.5 & 188 & 95.5 & 141 & 13 & 9.2 & 128 & 90.8 \\
\hline Zapotlanejo & 95 & 4 & 4.2 & 91 & 95.8 & 40 & 0 & 0 & 40 & 100.0 \\
\hline Teuchitlan & 70 & 30 & 42.8 & 40 & 57.2 & 46 & 15 & 32.6 & 31 & 77.4 \\
\hline Sayula & 112 & 10 & 8.9 & 102 & 91.1 & 30 & 1 & 3.3 & 29 & 96.7 \\
\hline La Huerta & 61 & 14 & 22.9 & 47 & 77.1 & 31 & 6 & 19.3 & 25 & 80.7 \\
\hline Ocotlan & 170 & 14 & 8.2 & 156 & 91.8 & 72 & 9 & 12.5 & 63 & 97.5 \\
\hline Totatiche & 52 & 2 & 3.8 & 50 & 96.2 & 14 & 12 & 85.7 & 2 & 14.3 \\
\hline Jocotopec & 60 & 3 & 5.0 & 57 & 95.0 & 31 & 6 & 19.3 & 25 & 80.7 \\
\hline San Cristobal de la Barranca & 148 & 0 & 0 & 146 & 100.0 & 82 & 3 & 3.6 & 79 & 96.4 \\
\hline Tolirnan & 78 & 6 & 7.6 & 72 & 92.4 & 34 & 6 & 17.6 & 28 & 82.4 \\
\hline Cuquio & 138 & 24 & 17.3 & 114 & 82.7 & 49 & 4 & 8.1 & 45 & 91.9 \\
\hline Totals & 2956 & 655 & 22.15 & 2301 & 77.85 & 22.38 & 276 & 12.33 & 19.62 & 87.67 \\
\hline
\end{tabular}


When correlating the serological results with the dwelling's characteristics, we noted that there had been improvements in the following areas: $18.94 \%$ of the roofs had been improved; $16.12 \%$ of the floors, and $9.7 \%$ of the walls.

\section{DISCUSSION}

When analyzing the above results, we found that the percentages of infection did not show a very extreme difference (from $22.15 \%$ n to $12.33 \%$ ), since these were obtained in relation to the number of study subjects; nevertheless, we found a high seroconversion, since $5.0(7.6 \%)$ individuals had become negative in a period of 7 years. Although one might raise the possibility of were flaws in the laboratory technique, this can be dismissed because in all the tests, positive and negative control sera were used, in addition to the fact that a number of sera were provided to the Chagas' Disease Research Laboratory at the School of Medicine in Goiânia, Brazil, and processed by Dr. Alejandro Luquetti (Reference laboratory). The same Tulawen strain was used (Argentina), and techniques of Wattman filter paper number 1 (the same as in the 1987 study) and total sera (to form a serum reference group) were processed.

It is worth mentioning that in the dwellings where improvements in roofs, floors, and walls were reported, no triatomids were found, and the people reported not having been bitten by barbeiros since the previous study (1987). Interestingly, the 50 individuals that became negative corresponded to the inhabitants of these houses. Therefore, we believe that not living in infested houses and no longer being bitten produces negative seroconversion of antibody presence, due to a good initial inmune response. When performing statistical analysis with the chisquare test, using the Mantel-Haenszel correction between the serology recorded in 1987 and that of 1994, we found a statistically significant difference with a p value of -0.05 ( $95 \%$ C.I.), and we found this same result by analyzing the presence of the vector with the serological results of the positive individuals in 1987 and 1994.
Luquetti (1987) studied 240 sera from megaesophagus patients in Goiânia, Brazil, analyzed by two serological techniques, and found that in $26(10.8 \%)$, both serological tests performed gave clear-cut negative results. Twenty-four of these cases were suspected to be of chagasic etiology because of the epidemiological and clinical data. In 11 out of 24 of these individuals, xenodiagnosis was performed, and two were found to be positive.

In view of this situation, it is obvious that either the immune response of Mexican individuals is different or the virulence of the Mexican strains may be not as great as those in South American countries. This accounts partially for the presence of only 600 cases of the disease in its 54 years of existence.

However, this is only a preliminary report on the 32 municipalities studied, and further analysis is necessary in the remaining 92 municipalities.

Thus, there is reason to conduct further research on individual immune response or to compare the biochemical structure of our $T$. cruzi strains with those from South America.

\section{ACKNOWLEDGEMENTS}

We wish to thank Dr. Alejandro Luquetti for his help with serological testing in this study.

\section{RESUMO}

TRUJILLO-CONTRERAS, F. \& YERENAS, M. A. V. Seguimento Sorológico de Infecção por Trypanosoma cruzi entre 1987 e 1994 em 32 Municípios do Estado de Jalisco, México (Relatório Preliminar).

Cad. Saúde Públ., Rio de Janeiro, 11 (3): 501-505, jul/set, 1995.

Em 1987, a Universidade de Guadalajara realizou um in1quérito sorológico sobre a prevalência da doença de Chagas em 124 municípios do Estado de Jalisco, México, chegando a uma taxa de 21.6 por 100 habitantes. Entre dezembro de 1993 a junho de 1994, os autores estudaram 2238 indivíduos de 32 municípios da área rural 
desse mesmo estado. Encontraram 276 positivos (12.33\%) a 1962 negativos $(87.66 \%)$. Entretanto, as séries de diferenças sorológicas foram muito marcantes, uma vez que dos 655 indivíduos que testaram positivos em 1987, 276 permaneceram positivos, enquanto 50 (7.63\%) tornaram-se soronegativos. Não houve falha de técnica laboratorial. Os autores acreditam que, ou a resposta imune dos mexicanos é diferente, ou então, que a virulência das cepas mexicanas de Trypanosoma cruzi não é tão intensa quanto aquela encontrada em países sulamericanos.

Palavras-Chave: Doença de Chagas; Sorologia; Infecção por Trypanosorna cruzi

\section{REFERENCES}

CASTRO, C.; REZENDE, J. M.; CAMARGO, M.; CERISOLA, A.; PRATA, A. \& MACEDO, V., 1984. Esofagopatia chagásica no município de Mambaí. Revista da Sociedade Brasileira de Medicina Tropical, 17 (Supl.): 31-32.

CUARTERO, L. M.; PONCE, D. \& RECCO, R., 1967. Cinco nuevos casos de enfermedad de Chagas en Zacatecas y Jalisco, en la República Mexicana. Revista de lnvestigación de Salud Pública, 27: 29-36.

HERNANDEZ, M. L; ERICSON, C. H. \& DELGADILLO, C., 1987. New focus of Chagas disease in Mexico. Lancet, 100: 23.
INSTITUTO NACIONAL DE DIAGNOSTICO Y REFERENCIA, 1991. La Enfermedad de Chagas. México, D.F.: Dirección General de Epidemiología, Secretaría de Salud. (Publicación Tecnica, 8)

LUQUETTI, A. O., 1987. Megaesôfago a anticorpos anti-Trypanosoma cruzi. Revista Goiana de Medicina, 33: 01-16.

MAZZOTI, L., 1940. Dos casos de enfermedad de Chagas en el estado de Oaxaca, México. Gaceta Médica Mexicana, 70: 417-420.

MINISTERIO DE SALUD Y ACCION SOCIAL, 1985. Manual sobre Enfermedad de Chagas. Buenos Aires, Argentina: Instituto Nacional de Diagnostico e Investigación de la Enfermedad de Chagas "Dr. Mario Fatala Chaben", Subsecretaría de Programas de Salud, Ministerio de Salud y Acción Social, Buenos Aires.

PRATA, A., 1985. Significance of Trypanosoma cruzi diferentiation and selection, relationship whit clinical and epidemiological varieties. Revista da Sociedade Brasileira de Medicina Tropical, 18 (Supl.): 09-16.

TRUJILLO-CONTRERAS, F.; MARTINEZ, L. C.; HERNANDEZ, R.; LOZANO, F. \& RUVALCABA, S., 1987. Estudio epidemiólogico de la prevalencia de la enfermedad de Chagas en el estado de Jalisco, México, 1987 (reporte preliminar). Revista de la Asociación Médica de Jalisco, Nueva Epoca, 3: 28-31.

WIENER LABORATORIOS, 1993. Chagatest HAI. Manual de Procedimientos. Rosario: Wiener Laboratorios. 